Mantle cell lymphoma has been recognized as a distinct entity from the other non-Hodgkin lymphomas in middle 1990's. It carries a worst prognosis among all mature B-cell malignancies. Cyclin D1 and recently SOX11 are the hallmarks for this disease. Even if it is highly responsive to induction treatment, it remains incurable, since it inevitably relapses. Highly aggressive approaches with stem cell transplantation can shift the survival curve for a bit, but even so the overall survival is not significantly improved in most of the cases. Small portion of patients with this heterogeneous disease have an indolent course with long-term survival. Conventional immunochemotherapy has reached its maximal possibilities, so novel target agents are absolutely warranted. The large number of ongoing early phase trials demonstrated promising results, especially emphasizing agents that target B-cell receptor. They are mostly investigated in relapsed/refractory disease, while front-line approaches with those agents need to be explored in future times.

Key words: mantle cell lymphoma, targeted agents, immunochemotherapy, stem cell transplantation.

Contemp Oncol (Pozn) 2014; 18 (6): 377-383 DOI: $10.5114 /$ wo.2014.45111

\section{Are we a step forward with targeted agents in resolving the enigma of mantle cell lymphoma?}

\author{
Ivan Petković ${ }^{1}$, Ivica Pejčićc, ${ }^{1,2}$, Svetislav Vrbici ${ }^{1,2}$
}

${ }^{1}$ Oncology Clinic Clinical Center Niš, Serbia

${ }^{2}$ Medical Faculty University of Niš, Serbia

\section{Introduction}

Mantle cell lymphoma (MCL) is a subtype of B-cell lymphomas first defined as a clinical entity distinct from the other non-Hodgkin lymphomas (NHL) in 1994 [1]. It accounts for $2-10 \%$ of all NHL, with male predominance (about 2.3-2.5:1) and a median age at presentation close to 70 years [2]. The stage usually is advanced, adenopathy typically is non-bulky, but extranodal involvement is frequent, such as bone marrow, liver, spleen, or Waldeyer ring. Gastrointestinal tract involvement, especially in a form of multiple lymphomatous polyposis (MLP) is the common presentation [3, 4]. A leukemic phase is not uncommon, but CNS involvement is unusual at presentation, yet can be seen upon relapse or when histology is blastic. Although morphologically similar, MCL is significantly more aggressive than other small cell lymphomas and therefore must be differentiated from them.

Mantle cell lymphoma is characterized by the chromosomal translocation t(11;14)(q13;q32), resulting in constitutional overexpression of cyclin D1 and cell cycle dysregulation in virtually all cases [5]. Cyclin D1 is detected by immunochistochemistry in $98 \%$ of $\mathrm{MCL}$, although in remaining cases it may lack [6]. Those cyclin D1 negative cases often show expression of cyclin D2 and cyclin D3 [7]. The SOX11 (neuronal transcriptional factor) is highly expressed in both cyclin D1 negative and positive MCL, suggesting that in addition to its value as a diagnostic biomarker, it may be an important factor in the pathogenesis of MCL [8].

The MCL International Prognostic Index (MIPI) is the prognostic model most often used as a predictive tool for overall survival (OS) rates. It incorporates: ECOG performance status, age, leukocyte count, and lactic dehydrogenase level. MIPI classifies patients in 3 risk subgroups (low, intermediate and high risk) with the portion of patients (44\%,35\% and $21 \%$ ), respectively. The median OS for the low risk group was not reached (5-year OS of 60\%), for the intermediate risk group was 51 months and 29 months for the high risk group [6]. Adding cell proliferation Ki67 index to MIPI (MIPI biological index-MIPI-B) is an important biological marker that showed strong additional prognostic relevance [9].

Conventional chemotherapy is only palliative and the median duration of remission (DOR) is only $1-2$ years. With the exception of allogeneic stem cell transplantation (allo-SCT), current treatment approaches are non-curative and corresponding survival curves are characterized by a delayed, but continuous decline and a median survival of 3 to 7 years [5]. Mantle cell lymphoma has the worst prognosis among all adult B-cell malignancies.

Novel agents targeting various molecular pathways are now in the focus of investigation mostly as phase II studies in relapsed/refractory disease. Awaiting phase III studies will show their accurate clinical benefit. 
Current overview of the induction approach to MCL patients

"Gold standard" CHOP/CHOP-like protocols (cyclophosphamide, doxorubicin, vincristine, prednisone) have been the main induction approach to MCL, for long period of time. After the introduction of rituximab (R) and its adjunction to CHOP chemotherapy, in the study of Lenz et al., it was demonstrated an increased overall response rate (ORR) from (76\% to $94 \%, p=0.0054$ ), and the complete remission rate (CR) from (7\% to 34\%, $p=0.00024)$, respectively [10]. Interestingly, this improvement does not translate into prolonged OS and even significantly better progression free survival (PFS). The results of a meta-analysis of randomized controlled trials in $(n=260) \mathrm{MCL}$ patients allegedly demonstrated survival benefit in patients treated with immunochemotherapy compared to those treated with chemotherapy alone [11]. Nevertheless, the number of patients included express doubts of the validity and the sufficient statistical power to confirm such findings. Elderly patients seem to have benefit of R-CHOP induction followed by rituximab maintenance therapy. This is not only in PFS but also in a significant survival advantage [12].

Treatment of MCL in younger patients is the most challenging, since the primary goal is to develop long-term remissions with prolongation of survival or to cure a patient, if possible. For transplant-eligible patients the standard of care is up-front induction therapy followed by autologous (auto-SCT) consolidation in first remission, especially in the intermediate risk group, whereas in the high risk group such an approach remains suboptimal. Randomized studies are needed to clarify the significance of allo-SCT in first remission, which seems to be the best known option to this time point [13].

There are many published trials which used R-HCVAD/ AM (hyperfractioned cyclophosphamide, high dose dexamethasone, vincristine, doxorubicin/high dose methotrexate and cytarabine) as an induction treatment followed by consolidation with auto-SCT. The Italian group published results for patients aged $\leq 70$ years who received 4 alternating cycles each of R-HCVAD/AM. Patients who obtained a partial response proceeded to auto-SCT. ORR and CR rates were $83 \%$ and $72 \%$, respectively. After a median follow-up of 46 months (range 1-72) the estimated 5-year OS and PFS rates were $73 \%$ and $61 \%$, respectively. MIPI maintained the prognostic value with an estimated 5-year OS of $89 \%, 80 \%$ and $24 \%$ for low, intermediate, and high risk groups, respectively $(p<0.001)$. This multicentre study confirmed that R-HCVAD-AM is an active regimen for the initial treatment of patients with MCL, but is associated with significant toxicity [14]. The authors of the SWOG 0213 trial had the same conclusions in patients aged $<65$ years, with median OS of 6.8 years [15]. The results of the GELTAMO group showed that induction with R-HCVAD-AM and consolidation with ${ }^{90}$ Y-ibritumumab tiuxetan is effective, although less feasible than expected. The substantial toxicity advised against the use of this strategy [16].

Polish single center experience study in patients was conducted. The median age of patients was 59 years (range 41-68) with $90 \%$ of stage $3 / 4 \mathrm{MCL}$. As an induction regi- men R-CHOP was used in all patients except 1 who received R-CVAD. All patients responded ( $n=13$ first CR, $n=4 \mathrm{sec}$ ond $(R$ and $n=3 P R$ ). The conditioning regimen was CBV (high dose cyclophosphamide, BCNU, etopozide) in ( $n=18)$ and BEAM (BCNU, etopozide, cytarabine and melphalan) in $(n=2)$ patients, respectively. Median OS and PFS were 48 and 29.8 months, respectively. The estimated 5-year OS and PFS were found to be $52 \%$ and $35 \%$, respectively. After median follow-up after auto-SCT of 36 months 10 patients were alive (8 remaining in CR, and 2 relapsed). Other 10 patients died from disease recurrence and subsequent chemoresistance. Authors concluded that auto-SCT consolidation for MCL patients is safe and effective procedure [17]. A French group of authors published their results of phase II study with CHOP and DHAP (high dose dexamethasone, etopozide, cytarabine, cisplatin) + rituximab followed by auto-SCT in MCL [18]. Included were patients aged $<66$ years with stage 3/4 MCL. As an induction treatment 3 cycles of CHOP (the third one was with the addition of rituximab) and 3 cycles of R-DHAP sequentially, were used. Responding patients were eligible for auto-SCT with conditional regimens (TAM 6 or BEAM). The ORR was 93\% after (R)-CHOP and 95\% after R-DHAP. With a median follow-up of 67 months, the median EFS were 83 months, and the median OS had not been reached. Five-year OS was 75\%. This study confirmed that induction with rituximab and cytarabine-based regimen is safe and effective in MCL patients. In an updated review of the Nordic MCL2 trial, median observation (6.5 years), the authors reported median OS and response duration longer than 10 years, and median EFS of 7.4 years. The MIPI and Ki67 expression were the only independent prognostic factors for EFS and OS. Subdivided by the MIPI-B, more than $70 \%$ of the patients with low-intermediate MIPI-B were alive at 10 years, in contrast to $23 \%$ of the patients with high MIPI-B. The conclusion was that risk-adopted treatment strategy is required [19]. The study of Eastern German Study Group Hematology/Oncology (OSHO) conducted in $(n=39)$, where $(n=33)$ responding patients proceeded allo-SCT after induction with R-CHOP/R-DHAP for de novo MCL, or R-DHAP for relapsed/refractory $\mathrm{MCL}$ demonstrated 5-year PFS of $67 \%$ and OS of 73\%. Enrolled were patients aged (18-65). Most of the patients received reduced intension conditioning (RIC) ( $n=26$ ) with TreoFlu (treosulfan, fludarabine) protocol-age $>55$ years and $(n=7)$ received myeloablative regimen BuCy (busulfan, cyclophosphamide) aged $<55$ years. The overall mortality after the procedure was $24 \%(n=8)$ with $(n=5)$ patients who relapsed after the procedure. The results were comparable between de novo MCL and relapsed/refractory MCL patients. The authors concluded that allo-SCT is a feasible and promising consolidation therapy for relapsed and refractory disease and an attractive option for young patients with de novo MCL of high risk and that significantly better outcome was in younger patients [20]. Summarized results of up-front use of SCT are presented in (Table 1).

Nevertheless, in younger transplant-eligible patients first line induction with R-HCVAD/AM followed by auto-SCT consolidation remains the standard of care with documented survival benefit, at this time point. The problem with this regimen is connected with the frequent stem cell mobilization failure and high toxicity rate. This implies the 
need for new front-line treatment strategy (Polish, French, Nordic MCL trials and OSHO) or consideration of an early stem cell collection, when R-HCVAD/ AM induction regimen is to be used. One is clear that high doses cytarabine containing regimens should be used before proceeding SCT in transplant-eligible MCL patients.

Some very new statements [21] are questioning the role of SCT consolidation approach in first remission, especially in the era of an improved survival and higher response rates with immunochemotherapy. This might be due to the heterogeneity of some clinical factors that have to be considered (patient age, MIPI or comorbidity index scores) before making a decision on SCT. The most current trial (the comparison of R-CHOP+R-DHAP sequential induction followed by consolidation with auto-SCT and ibrutinib maintenance arm vs. the same combination but without auto-SCT, followed only with ibrutinib maintenance therapy arm) will try to define the role of SCT consolidation in first remission. This was orally presented by Prof. Dreyling at European Hematology Association (EHA 19) Congress 2014 in Milan.

\section{Targeted agents in mantle cell lymphoma}

As above mentioned, optimal treatment approach to $M C L$ is undefined. This disease still remains incurable with almost inevitable relapse over time period of remission, whatever approach is used. Novel targeted agents are infallible needed. Many of them are included in various numbers of studies, mostly phase II with more than promising results, among some of them. However, larger phase III studies are required to determine real clinical benefit of those novel therapies. The aim of this review article will be to summarize an updated treatment approaches and recent study results through consideration of different mo- lecular target pathways. Summarized results of efficacy of targeted agents in MCL are presented in (Table 2).

\section{Inhibitors of mammalian target of rapamycin}

The mammalian target of rapamycin (mTOR) is an intracellular kinase that controls the mRNA translation of many proteins (eg, cyclin D1 in $\mathrm{MCL}$ ) that can act as oncogenes and contribute to lymphomagenesis [22]. Temsirolimus as the first generation mTOR inhibitor agent was investigated in phase II and III trials in MCL In two phase II studies, first conducted in $(n=35)$ patients, the ORR for the single-agent temsirolimus $250 \mathrm{mg}$ was 38\% and the DOR for responders was 6.9 months [23], and in the second one single-agent temsirolimus $25 \mathrm{mg}$ dose, 3 years later, in ( $n=29$ ) patients the ORR was $41 \%$, with median DOR in responders of 6 months [24]. In pivotal phase III study in $(n=162)$ patients who were randomized as $1: 1: 1-(175 \mathrm{mg}$ weekly for 3 weeks followed by either $75 \mathrm{mg}$ (175/75 mg), $25 \mathrm{mg}(175 / 25 \mathrm{mg})$ weekly, or investigator's choice therapy from prospectively approved options). It was found that 175/75 mg dose schedule significantly improved PFS and objective ORR of 22\% compared with investigator's choice therapy (ORR of $2 \%$ ) in patients with relapsed/refractory $\mathrm{MCL}$ [25]. The safety profile of temsirolimus is mostly acceptable and manageable with dose modifications or medical interventions [26]. In multicenter phase II study with single-agent everolimus with $(n=35)$ patients enrolled, the ORR was 20\%, median PFS was 5.5 months and 17 months for responders (those who received 6 or more cycles of therapy) [27].

\section{Proteasome inhibitors}

The proteasome inhibitors are agents that block the action of proteasomes, cellular cylindrical complexes that

Table 1. Summarized review of the outcome in patients who proceeded SCT (auto or allo)

\begin{tabular}{|c|c|c|c|c|c|c|}
\hline Reference & $\begin{array}{c}\text { Number of } \\
\text { patients enrolled }\end{array}$ & $\begin{array}{c}\text { Induction } \\
\text { protocol + type of SCT }\end{array}$ & ORR & $\begin{array}{l}\text { Median follow-up in } \\
\text { the study [months] }\end{array}$ & PFS & $\begin{array}{l}\text { Median OS } \\
\text { [months] }\end{array}$ \\
\hline [14] & $\begin{array}{c}(n=63) \\
60 \\
\text { eligible }\end{array}$ & $\begin{array}{l}\text { R-HCVAD alternating } \\
\qquad \mathrm{AM}+ \\
\text { auto-SCT }\end{array}$ & $\begin{array}{c}83 \% \\
73 \% \mathrm{CR}\end{array}$ & 46 months & $\begin{array}{l}\text { estimated median } \\
5 \text {-years PFS } 61 \%\end{array}$ & $\begin{array}{c}\text { estimated } \\
\text { median 5-year } \\
\text { OS } 73 \%\end{array}$ \\
\hline$[15]$ & 49 & $\begin{array}{c}\text { R-HCVAD alternating } \\
\text { AM + } \\
\text { auto-SCT }\end{array}$ & $\begin{array}{c}86 \% \\
47 \% \text { CR }\end{array}$ & $\begin{array}{c}4.8 \text { years } \\
\text { (58 months) }\end{array}$ & $\begin{array}{c}\text { median PFS } \\
4.8 \text { years } \\
\text { estimated } 5 \text {-year } \\
\text { PFS } 49 \%\end{array}$ & $\begin{array}{c}\text { median OS } \\
6.8 \text { years } \\
\text { estimated } \\
\text { median } 5 \text {-years } \\
63 \%\end{array}$ \\
\hline$[17]$ & 20 & $\begin{array}{l}\text { R-CHOP/ R-CVAD in } 1 \\
\text { patient }+ \\
\text { auto-SCT }\end{array}$ & $\begin{array}{l}100 \% \\
85 \% \mathrm{CR}\end{array}$ & 36 months & $\begin{array}{l}48 \text { months } \\
\text { estimated 5-year } \\
\text { PFS 35\% }\end{array}$ & $\begin{array}{c}29.8 \text { months } \\
\text { estimated 5-year } \\
\text { OS 52\% }\end{array}$ \\
\hline [18] & 60 & $\begin{array}{c}\text { (R)-CHOP } \times 3 / \text { R-DHAP } \times 3+ \\
\text { auto-SCT }\end{array}$ & $\begin{array}{l}93-95 \% \\
57 \% \text { CR }\end{array}$ & 67 months & 84 months & $\begin{array}{c}\text { not reached, } \\
\text { 5-year OS 75\% }\end{array}$ \\
\hline [19] & $\begin{array}{c}(n=160) \\
145 \text { proceeded } \\
\text { SCT }\end{array}$ & $\begin{array}{c}\text { maxiCHOP alternating } \\
\text { with HD cytarabine + } \\
\text { auto-SCT }\end{array}$ & $\begin{array}{l}96 \% \\
54 \% \text { CR }\end{array}$ & $\begin{array}{c}6.5 \text { years } \\
\text { (112 months) }\end{array}$ & $\begin{array}{l}\text { at } 10 \text {-years not } \\
\text { reached } \\
\text { EFS } 7.4 \text { years as } \\
\text { intent to treat }\end{array}$ & $\begin{array}{l}\text { at } 10 \text {-years not } \\
\text { reached }\end{array}$ \\
\hline [20] & 33 & $\begin{array}{c}\text { R-CHOP/R-DHAP for de } \\
\text { novo MCL, or R-DHAP } \times 4 \\
\text { for R/R MCL + } \\
\text { allo-SCT }\end{array}$ & $60 \%$ & $\begin{array}{l}2.8 \text { years } \\
\text { (32 months) }\end{array}$ & $\begin{array}{c}\text { 5-year PFS was } \\
67 \%\end{array}$ & $\begin{array}{c}5 \text {-year OS was } \\
73 \%\end{array}$ \\
\hline
\end{tabular}


Table 2. Summarized review of targeted agents efficacy in relapsed/refractory MCL

\begin{tabular}{|c|c|c|c|c|c|c|}
\hline Reference & $\begin{array}{l}\text { Phase } \\
\text { of the } \\
\text { study }\end{array}$ & $\begin{array}{l}\text { Number } \\
\text { of patients } \\
\text { enrolled }\end{array}$ & Agent investigated & ORR & $\begin{array}{c}\text { PFS } \\
\text { [months] }\end{array}$ & $\begin{array}{l}\text { Median OS } \\
\text { [months] }\end{array}$ \\
\hline [23] & $\|$ & 35 & $\begin{array}{c}\text { temsirolimus } 250 \text { mg - } \\
\text { single agent }\end{array}$ & $38 \%$ & 6.5 & 12 \\
\hline$[24]$ & $\|$ & 29 & $\begin{array}{l}\text { temsirolimus } 25 \text { mg - } \\
\text { single agent }\end{array}$ & $41 \%$ & $\begin{array}{l}6 \text { median DOR, } \\
\text { PFS not evaluated }\end{array}$ & 14 \\
\hline$[25]$ & III & 162 & $\begin{array}{l}\text { temsirolimus } 175 / 75 \mathrm{mg}- \\
\text { single agent }\end{array}$ & $22 \%$ & 4.8 & 12.8 \\
\hline$[27]$ & $\|$ & 35 & everolimus - single agent & $20 \%$ & $\begin{array}{l}5.5 \text { and } 17 \text { for } \\
\text { responders }\end{array}$ & not evaluated \\
\hline [28] & II & $\begin{array}{c}\text { 155/assessable } \\
n=141\end{array}$ & bortezomib - single agent & $33 \%$ & $\begin{array}{l}9.2 \text { median DOR, } \\
\text { PFS not evaluated }\end{array}$ & $\begin{array}{l}\text { not reached after } \\
13.4 \text { months of } \\
\text { follow-up }\end{array}$ \\
\hline $\begin{array}{c}{[29]} \\
\text { Up-dates of the } \\
\text { same study in } \\
{[27]}\end{array}$ & II & 141 & bortezomib - single agent & $32 \%$ & $\begin{array}{l}4.1-4.5 \text {, refractory } \\
\text { vs. patients with } \\
\text { prior HD therapy }\end{array}$ & $\begin{array}{l}23.5 \text { and } 35.4 \text { for } \\
\text { responders }\end{array}$ \\
\hline$[30]$ & II & 40 & bortezomib - single agent & $47 \%$ & $\begin{array}{l}\text { 5.6-3.9 relapsed vs. } \\
\text { refractory, } \\
\text { responders: } \\
\text { 7.8-8.4 relapsed vs. } \\
\text { refractory }\end{array}$ & not evaluated \\
\hline [31] & II & $\begin{array}{l}n=25 \text { both } \mathrm{FL} / \\
\text { MCL patients }\end{array}$ & rituximab + bortezomib & $29 \%$ & $\begin{array}{l}\text { estimated PFS } \\
24 \% \text {, and } 60 \% \text { in } \\
\text { responders }\end{array}$ & not evaluated \\
\hline$[32]$ & II & 16 & $\begin{array}{l}\text { rituximab + bortezomib + } \\
+ \text { dexamethasone }\end{array}$ & $81.3 \%$ & $\begin{array}{l}12.1 \text { and } 38.7 \text { if } C R \\
\text { was obtained }\end{array}$ & $\begin{array}{l}38.6 \text { and not } \\
\text { reached for } \\
\text { patients who } \\
\text { achieved CR }\end{array}$ \\
\hline$[32]$ & $\|$ & 16 & thalidomide + rituximab & $81 \%$ & 20.4 & $\begin{array}{l}\text { estimated for } 36 \\
\text { months }-75 \%\end{array}$ \\
\hline [33] & $\|$ & 134 & lenalidomide - single agent & $28 \%$ & 4 & 19 \\
\hline [23] & $\|$ & $\begin{array}{c}5 \\
\text { only } \mathrm{MCL} \\
\text { patients }\end{array}$ & $\begin{array}{c}\text { lenalidomide + low } \\
\text { dose-dexamethasone + } \\
\quad+\text { rituximab }\end{array}$ & $58 \%$ & $\begin{array}{l}\text { no evidence } \\
\text { for } M C L\end{array}$ & $\begin{array}{l}\text { no evidence } \\
\text { for } M C L\end{array}$ \\
\hline$[35]$ & 1 & $\begin{array}{l}10 \text { only } M C L \\
\text { patients }\end{array}$ & $\begin{array}{c}\text { flavopiridol + rituximab + } \\
\text { + fludarabine }\end{array}$ & $80 \%$ & $\begin{array}{l}21.9 \text { and } 35.9 \text { for } \\
\text { non-blastoid MCL }\end{array}$ & not evaluated \\
\hline$[38]$ & $\|$ & 111 & ibrutinib - single agent & $68 \%$ & $\begin{array}{l}\text { estimated } \\
13.9\end{array}$ & $\begin{array}{l}\text { not reached, } \\
\text { estimated } 58 \% \text { for } \\
18 \text { months }\end{array}$ \\
\hline$[41]$ & 1 & 40 & idelalisib - single agent & $40 \%$ & $\begin{array}{c}3.7 \text { with } 1 \text {-year PFS } \\
\text { of } 22 \%\end{array}$ & not evaluated \\
\hline
\end{tabular}

HD therapy - high dose therapy; FL - follicular lymphoma

break down proteins which are damaged or unneeded in cell. By blocking those systems cells are collecting warped proteins and dies. The PINNACLE study of Fisher RI et al., led to the acceptance of bortezomib in relapsed/refractory MCL. The study enrolled $(n=155)$ patients, previously treated (1-3 prior therapies) with median follow-up of 13.4 months. Results showed that in $(n=141)$ assessable patients, ORR was $33 \%$ with $8 \%$ of CR, median DOR was 9.2 months and median OS was not reached. The administration schedule, as well the adverse effects of bortezomib was the same as in multiple myeloma treatment [28]. Updated time-to-event evaluation of this study showed that median OS was 23.5 months. Responders had expectable better results with the median OS of 35.4 months. Patients achieved CR had heterogeneous disease characteristics of MCL [29]. O' Connor OA et al., conducted multicenter phase II PINNACLE study $(n=40)$ with heavily pretreated MCL patients. The ORR was $47 \%$ with $5 \%$ CR and $14 \%$ PR. The relapsed and primary refractory patients achieved ORR of $50 \%$ and $43 \%$, respectively, while PFS was almost 
similar. The collected data suggest that MCL patients with refractory or poorly responsive disease may still derive meaningful clinical benefit from the treatment with bortezomib [30]. In early clinical model of the phase II study that included rituximab to bortezomib, which enrolled $(n=25)$ patients with MCL and follicular lymphoma (FL), the ORR was $40 \%$ for both arms, while MCL patients had ORR of $29 \%$. The estimated PFS was $24 \%$ in all and $60 \%$ in responding patients. Although significant activity of this combination, the safety profile found to be of limiting clinical applicability (grade 3 neurotoxicity was delivered in $52 \%$ of patients) [31]. The phase II study $(n=16)$ patients enrolled of triple combination bortezomib, rituximab and dexamethasone gave ORR of over $81 \%$ with $43.8 \%$ patient achieved CR. The median PFS and OS were 12.1 and 38.6 months, respectively. In responding patients median PFS and OS have not yet been reached. This combination has promising activity with manageable toxicity in heavily pretreated patients with $M C L$ [32]. In responding patients bortezomib as a single-agent is associated with lengthy responses and notable survival in patients with relapse/ refractory $M C L$, suggesting substantial clinical benefit [29], although the addition of rituximab or dexamethasone significantly increases ORR, those combinations are decreasing their safety profiles.

\section{Immunomodulatory agents or drugs}

Immunomodulatory drugs (IMiDs) target microenvironment and neoangiogenesis of the tumor and have immunomodulatory activity. We found only one published trial with thalidomide and rituximab in relapsed/refractory MCL. It included $(n=16)$ patients. Objective response was achieved in $81 \%$ of patients, with 5 CR (31\%). Median PFS was 20.4 months and estimated 3-year survival was 75\%. In responders PFS was expectably longer. The study suggested that rituximab plus thalidomide has marked activity in relapsed/refractory $M C L$ with low toxicity profile [33]. In phase II MCL-001 (EMERGE) trial single-agent lenalidomide was investigated in relapsed/refractory or patients who progressed after bortezomib. Study included $(n=134)$ patients, median age of 67 with a median prior therapies (range 2-10). The achieved ORR was $28 \%$ with $7.5 \% \mathrm{CR}$, median DOR was 16.6 months, median PFS 4 months and median OS 19 months. This study showed durable efficacy of lenalidomide after the progression on bortezomib [34]. The combination of lenalidomide, low-dose dexamethasone, and rituximab achieved high response rates with durable responses in patients with rituximab-resistant, indolent B-cell lymphomas and MCL $(n=5)$ in this phase II study. ORR increased from $29 \%$ after two 28 -day cycles of lenalidomide and low-dose dexamethasone to $58 \%$ after the addition of rituximab, suggesting that lenalidomide can overcome resistance to rituximab [35].

\section{Cyclin-dependent kinase inhibitors}

Cyclin-dependent kinases (CDK) are a family of protein kinases which have the role in cell cycle regulation. They are coded by CDK genes. This small molecules binds with regulatory proteins called cyclines and become full active and than phosphorilate their substrates. CDK inhibitors (CDKi) target cyclin-dependent kinases and are involved in cell cycle arrest at G1 phase. The phase I study of Lin TS et al., with flavopiridol (NSC-649890) added to rituximab and fludarabine (FFR) regimen was investigated in indolent lymphomas of which one group included $\mathrm{MCL}$ $(n=10)$. The MCL patients (median age 68 , of whom 6 were untreated and 4 relapsed patients who had each received two prior therapies), received a median of 3.5 cycles. Eight patients responded (7 had CR, 1 PR). Median PFS was 21.9 months, ranging from 1.1 months when a patient withdrew to receive another regimen to at least 68.2 months. Two patients with blastoid variant MCL responded but relapsed within 1 year of study entry. Median PFS of the eight patients with non-blastoid MCL was 35.9 months. This regimen appeared to be most promising in older MCL patients with acceptable toxicity. However, results indicate a larger phase II study in previously untreated or relapsed disease to define regimen's activity across the MIPI risk group [36]. Furthermore, findings from this study suggest that FFR may be active in a particular histology of $M C L$ even if flavopiridol demonstrates limited clinical activity as monotherapy for that particular lymphoma [37]. The single-agent activity of this first-generation CDKi suggests that other agents in this class merit further study in lymphoid malignancies, both alone and in combination [38].

\section{Bruton's tyrosine kinase inhibitors}

The Bruton's tyrosine kinase (BTK) is a mediator of the $B$-cell receptor signaling pathway. Its gene is located on $X$ chromosome and it plays a crucial role in B cell maturation, but exact mechanism of action remains unknown at this moment. The potent inhibitor of this pathway-ibrutinib (PCl-32765), have demonstrated the power to induce impressive responses in B-cell malignancies through irreversible bond with cysteine-481 in the active site of BTK (TH/SH1 domain) and inhibits BTK phosphorylation on Tyr 223 [39]. Phase I studies have pointed to its antitumor activity in MCL. Afterword, pivotal phase II study, conducted on $(n=111)$ patients with relapsed/refractory MCL, at daily doses of $560 \mathrm{mg}$ (patients previously received at least 2 cycles of bortezomib or less, or who had no received bortezomib), with median age of 68 years and $86 \%$ of patients had intermediate or high risk disease, showed ORR of $68 \%$ with $21 \%$ CR rate and PR of $47 \%$. The estimated median follow up was 15.3 months, with the estimated DOR of 17.5 months, median PFS 13.9 months and median OS not reached (estimated OS rate was $58 \%$ at 18 months). This study concluded durable single agent efficacy of ibrutinib in relapsed/refractory MCL [40]. Axelrod et al., have performed a preclinical combinatorial screen of ibrutinib and carfilzomib as a targeted agents that could provide improved clinical response. All 4 cell lines responded to the combination of proteasome and BTK inhibition, including Jeko-1, a leukemic, classically indolent form of MCL, and Z138, a blastic, characteristically aggressive form of MCL, suggesting that the carfilzomib and ibrutinib combination may prove efficacious regardless of variations in specific patient MCL tumor biology. The study suggested 
that combination of agents not targeting BTK with ibrutinib provides higher benefit, over combination with two BTK inhibitors [41]. Awaiting phase III trials with ibrutinib will show its real clinical benefit.

\section{Phosphatydilinosytol 3-kinase $\delta$ inhibitors}

Idelalisib (CAL-101, GS-1101) is a phosphatydilinosytol

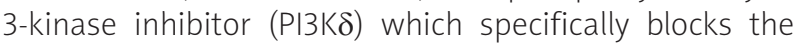
delta isoform of the enzyme $110 \delta$. This isoform plays a critical role in B-cell homeostasis and function. It was evaluated in phase I study in $(n=40)$ patients with relapsed/refractory MCL. Patients who entered the study had median age of 69 years and received 4 prior therapies and were refractory to their most recent treatment. ORR was $40 \%$, with CR in $5 \%$ of patients. Median DOR was 2.7 months, median PFS was 3.7 months, and 1-year PFS was $22 \%$. These data provide proof of concept that targeting $\mathrm{PI} 3 \mathrm{~K} \delta$ is a viable strategy and worthy of additional study in MCL [42]. Safety profile of idelalisib in this study showed moderate adverse events.

\section{Other agents in most current trials}

In phase II study the addition of bevacizumab (monoclonal antibody that blocks VEGF) to the standard R-CHOP regimen in $(n=11)$ MCL patients as induction approach did not appear to significantly improve efficacy beyond that observed from previous studies using R-CHOP alone [43]. The phase II study investigated histone deacetylase (HDAC) inhibitor-vorinostat in patients with relapsed/refractory indolent B-cell lymphomas and MCL $(n=4)$ patients. First results showed moderate ORR, but results are mostly based for FL. Those results warrant further investigations of this agent for MCL [44]. The second HDAC inhibitor-panobinostat was investigated in phase I study but with small number of relapsed/refractory MCL patients concomitant with everolimus, this combination found to be active especially in Hodgkin lymphoma but is associated with severe thrombocytopenia [45]. There are many pre-clinical investigations of MCL cell lines with very promising results which awaits clinic introduction in future times.

Today, we know that MCL is very heterogeneous disease with approximately $15 \%$ of patients with an indolent course, slow in progress which could be hold only with "watch and wait" strategy. However, in remaining percentage it behaves aggressively or it inevitably relapses after induction treatment, so new agents are ultimately required or rather we need to change the current treatment paradigm by introducing new agents. Furthermore, risk stratification by using MIPI, MIPI-B as predictive tools should be incorporated in treatment decisions. The possibilities of conventional imunochemotherapy in $\mathrm{MCL}$ without SCT are well established. SCT is the only measure that can shift the survival curve, but it still remains unclear if long-remissions are possible. Auto-SCT gives the opportunity of durable remissions in younger fit patient, but late relapses still occur. Allo-SCT has curative potential, however with poor applicability, due to its toxic potential and high procedure-related mortality rates, especially in pretreated patients and the median age when MCL mostly occur. Large number of patients is not feasible for such radical options, so the procedure has to be limited only for those patients who will have the optimal benefit. Nevertheless, by using RIC regimens it might become more widely applicable, but still in highly selected group of patients (younger, fit, and with high risk who does not have any choice for longer survival with other approaches). Mantle cell lymphoma is still considered as incurable disease, but something is definitely changing. The recent period of investigations has demonstrated some progress which could be found to be encouraging. As from that point of view, ibrutinib even as a single agent has demonstrated long time expected promising results like no other agent did in past history of MCL treatment. This agent is now included in large number of trial combinations and the results are still expected. Did we make a step forward with targeted agents? We can conclude that slight approach to the target has been made, but still need a time to see are we really close enough to solve the enigma of MCL.

The authors declare no conflict of interest.

\section{References}

1. Harris NL, Jaffe ES, Stein $H$, et al. A revised European-American classification of lymphoid neoplasms: a proposal from the International Lymphoma Study Group. Blood 1994; 84: 1361-92.

2. Smedby KE, Hjalgrim H. Epidemiology and etiology of mantle cell lymphoma and other non-Hodgkin lymphoma subtypes. Semin Cancer Biol 2011; 21: 293-8.

3. Trozzi PL, Borowitz MJ, Gockerman JP. Gastrointestinal involvement and multiple lymphomatous polyposis in mantle-zone lymphoma. J Clin Oncol 1986; 4: 866-73.

4. Petković I, Mihailović D, Krstić M, et al. Primary mantle cell lymphoma of gastrointestinal tract - a case report. Acta Medica Medianae 2012; 51: 41-6.

5. Dreyling M, Kluin-Nelemans HC, Beà S, et al. Update on the molecular pathogenesis and clinical treatment of mantle cell lymphoma: report of the 11th Annual Conference of the European Mantle Cell Lymphoma Network. Leuk Lymphoma 2013; 54: 699-707.

6. Vose JM. Mantle cell lymphoma: 2013 Updates on diagnosis, risk-stratification, and clinical management. Am J Hematol 2013; 88: 1082-8.

7. Rosenwald A, Wright G, Wiestner A, et al. The proliferation gene expression signature is a quantitative integrator of oncogenic events that predict survival in mantle cell lymphoma. Cancer Cell 2003; 3: 185-97.

8. Mozos A, Royo C, Hartmann E, et al. SOX11 expression is highly specific for mantle cell lymphoma and identifies the cyclin D1-negative subtype. Haematologica 2009; 94: 1555-62.

9. Hoster E, Dreyling M, Klapper W, et al.; German Low Grade Lymphoma Study Group (GLSG); European Mantle Cell Lymphoma Network. A new prognostic index MIPI for patients with advanced-stage mantle cell lymphoma. Blood 2008; 111: 558-65.

10. Lenz G, Dreyling M, Hoster E, et al. Immunochemotherapy with Rituximab and Cyclophosphamide, Doxorubicin, Vincristine, and Prednisone significantly improves response and time to treatment failure, but not long-term outcome in patients with previously untreated mantle cell lymphoma: results of prospective randomized trial of German low grade lymphoma study group (GLSG). I Clin Oncol 2005; 23: 1984-92.

11. Shulz H, Bohlius JF, Trelle S, et al. Immunochemotherapy with rituximab and overall survival in patients with indolent or mantle cell lymphoma: a systematic review and meta-analysis. J Natl Cancer Inst 2007; 99: 706-14. 
12. Kluin-Nelemans HC, Hoster E, Hermine J, et al. Treatment of older patients with mantle-cell lymphoma. N Engl J Med 2012; 367: 520-31.

13. Pejčić I, Petković I, Vrbić S, Filipovic S, Balic M, Cvetanovic A. Mantle cell lymphoma-current literature overview. J Buon 2014; 19: 342-9.

14. Merli F, Luminari S, Ilauricci F et al. Rituximab plus HyperCVAD alternating with high dose cytarabine and methotrexate for the initial treatment of patients with mantle cell lymphoma; a multicenter trial from Gruppo Italiano Studio Linfomi. Br J Haematol 2012; 156: 346-53.

15. Bernstein SH, Epner E, Unger M, et al. A phase II multicenter trial of hyperCVAD MTX/AraC-C and rituximab in patients with previously untreated mantle cell lymphoma; SWOG 0213. Ann Oncol 2013; 24: 1587-93.

16. Arranz R, Garcia-Noblejas A, Grande C, et al. First-line treatment with rituximab-hyperCVAD alternating with rituximab-methotrex ate-cytarabine and followed by consolidation with 90Y-ibritumomab-tiuxetan in patients with mantle cell lymphoma. Results of a multicenter, phase 2 pilot trial from the GELTAMO group. Haematologica 2013; 98: 1563-70.

17. Szcześniak M, Armatys A, Kurzawa R, et al. Autologous stem cell transplantation for mantle cell lymphoma-single centre experience. Contemp Oncol (Pozn) 2013; 17: 456-9.

18. Delarue R, Haioun C, Ribraq V, et al.; Groupe d'Etude des Lymphomes de l'Adulte (GELA). CHOP and DHAP plus rituximab followed by autologous stem cell transplantation in mantle cell lymphoma: a phase 2 study from the Groupe d'Etude des Lymphomes de l'Adulte. Blood 2013; 121: 48-53.

19. Geisler CH, Kolstad A, LAurell A, et al.; Nordic Lymphoma Group. Nordic MCL2 trial update: six-year follow-up after intensive immunochemotherapy for untreated mantle cell lymphoma followed by BEAM or BEAC+autologous stem-cell support: still very long survival but late relapses do occur. Br J Haematol 2012; 158: 355-62.

20. Krüger WH, Hirt C, Basara N, et al. Allogeneic stem cell transplantation for mantle cell lymphoma-final report from the prospective trials of the East German Study Group Hematology/Oncology (OSHO). Ann Hematol 2014; 93: 1587-97.

21. Chaudhary L, Kharfan-Dabaja MA, Hari P, Hamadani M. Is hemato poietic cell transplantation still a valid option for mantle cell lymphoma in first remission in the chemoimmunotherapy-era? Bone Marrow Transplant 2013; 48: 1489-96.

22. Hess G, Smith SM, Berkenblit A, et al. Temsirolimus in mantle cell lymphoma and other non-Hodgkin lymphoma subtypes. Semin Oncol 2009; 36 suppl 3: 37-45.

23. Witzig TE, Geyer SM, Ghobrial I, et al. Phase II trial of single agent temsirolimus (CCl-779) for relapsed mantle cell lymphoma. J Clin Oncol 2005; 23: 5347-56.

24. Ansell SM, Inwards DJ, Rowland KM, et al. Low-dose, single-agent temsirolimus for relapsed mantle cell lymphoma: a phase II tria in the North Central Cancer Treatment Group. Cancer 2008; 113: 508-14.

25. Hess G, Herbrecht R, Romaguera J, et al. Phase III study to evaluate temsirolimus compared with investigator's choice therapy for the treatment of relapsed or refractory mantle cell lymphoma. J Clin Oncol 2009; 27: 3822-9.

26. Coiffier B. Clinical efficacy and management of temsirolimus in patients with relapsed and refractory mantle cell lymphoma. Clin Lymphoma Myeloma Leuk 2013; 13: 351-9.

27. Renner C, Zinzani PL, Gressin R, et al. A multicenter phase II trial (SAKK 36/06) of single-agent everolimus (RAD001) in patients with relapsed or refractory mantle cell lymphoma. Haematologica 2012; 97: 1085-91.

28. Fisher RI, Bernstein SH, Kahl BS, et al. Multicenter phase II study of bortezomib in patients with relapsed or refractory mantle cell lymphoma. J Clin Oncol 2006; 24: 4867-74.

29. Goy A, Bernstein SH, Kahl BS, et al. Bortezomib in patients with relapsed or refractory mantle cell lymphoma: updated time-toevent analyses of the multicenter phase 2 PINNACLE study. Ann Oncol 2009; 20: 520-5.

30. O'Connor OA, Moskowitz C, Portlock C, et al. Patients with chemotherapy-refractory mantle cell lymphoma experience high response rates and identical progression-free survivals compared with patients with relapsed disease following treatment with single agent bortezomib: results of a multicentre Phase 2 clinical trial. Br J Haematol 2009; 145: 34-9.

31. Baiocchi RA, Alinari L, Lustberg ME, Lin TS, Porcu P, Li X, Johnston JS, Byrd JC, Blum KA. Phase 2 trial of rituximab and bortezomib in patients with relapsed or refractory mantle cell and follicular lymphoma. Cancer 2011; 117: 2442-51.

32. Lamm W, Kaufmann H, Raderer M, Hoffmann M, ChottA, Zielinski C, Drach J. Bortezomib combined with rituximab and dexamethasone is an active regimen for patients with relapsed and chemotherapy-refractory mantle cell lymphoma. Haematologica 2011; 96: 1008-14.

33. Kaufmann H, Raderer M, Wöhrer S, Püspök A, Bankier A, Zielinski C, Chott A, Drach J. Antitumor activity of rituximab plus thalidomide in patients with relapsed/refractory mantle cell lymphoma. Blood 2004; 104: 2269-71.

34. Goy A, Sinha R, Eilliams ME, et al. Single-agent lenalidomide in patients with mantle-cell lymphoma who relapsed or progressed after or were refractory to bortezomib: phase II MCL-001 (EMERGE) study. J Clin Oncol 2013; 31: 3688-95.

35. Ahmadi T, Chonq EA, Gordon A, Aqui NA, Nasta SD, Svoboda J, Mato AR, Schuster SJ. Combined lenalidomide, low-dose dexamethasone, and rituximab achieves durable responses in rituximab-resistant indolent and mantle cell lymphomas. Cancer 2014; 120: 222-8.

36. Lin TS, Blum KA, Fischer DB, et al. Flavopiridol, fludarabine, and rituximab in mantle cell lymphoma and indolent B-cell lymphoprolifrative disorders. J Clin Oncol 2010; 28: 418-23.

37. Hoster E, Dreyling M, Klapper W, et al.; German Low Grade Lymphoma Study Group (GLSG); European Mantle Cell Lymphoma Network. A new prognostic index (MIPI) for patients with advanced-stage mantle cell lymphomas. Blood 2008; 111: 558-65.

38. Jones JA, Rupert AS, Poi M, et al. Flavopiridol can be safely administered using a pharmacologically derived schedule and demonstrates activity in relapsed and refractory non-Hodgkin's lymphoma. Am J Hematol 2014; 89: 19-24.

39. Wang ML, Rule S, Martin P, et al. Targeting BTK with ibrutinib in relapsed or refractory mantle-cell lymphoma. N Engl J Med 2013; 369: 507-16.

40. Novero A, Ravella PM, Chen Y, Dous G, Liu D. Ibrutinib for B cell malignancies. Exp Hematol Oncol 2014; 3: 4.

41. Axelrod M, Ou Z, Brett LK, et al. Combinatorial drug screening identifies synergistic co-targeting of Bruton's tyrosine kinase and the proteasome in mantle cell lymphoma. Leukemia 2014; 20: 407-10.

42. Kahl BS, Spurgeon SE, Furman RR, et al. Results of a phase I study od idelalisib, a PIK3 $\delta$ inhibitor, in patients with relapsed or refractory mantle cell lymphoma (MCL). Blood 2014; 123: 3398-405.

43. Ruan J, Gregory SA, Christos P, et al. Long-term follow-up of R-CHOP with Bevacizumab as initial therapy for mantle cell lymphoma: Clinical and correlative results. Clin Lymphoma Myeloma Leuk 2014; 14: 107-13.

44. Ogura M, Ando K, Suzuki T, et al. A multicenter phase II study of vorinostat in patients with relapsed or refractory indolent B-cell non Hodgkin lymphoma and mantle cell lymphoma. Br J Haematol 2014; 165: 768-76.

45. Oki Y, Buglio D, Fanale M, et al. Phase I study of panobinostat plus everolimus in patients with relapsed or refractory lymphoma. Clin Cancer Res 2013; 19: 6882-90.

\section{Address for correspondence}

\section{Ivan Petković}

Oncology Clinic

Clinical Center Niš

Bulevar Dr Zorana Djindjica 48

18000 Nis, Serbia

e-mail: ivan76.unsu@yahoo.com

Submitted: 8.05 .2014

Accepted: 23.07.2014 